\title{
The "Pandemic" and the Differend
}

\author{
Bert Olivier \\ https://orcid.org/0000-0002-3138-1948 \\ University of the Free State \\ OlivierG1@ufs.ac.za
}

\section{Abstract}

Jean-Francois Lyotard's concept of "the differend" enables one to gain a purchase on the plethora of clashing, divergent discourses or opinions characterising the current historical era, that of the coronavirus "pandemic" (Covid-19), in so far as this concept enables one to discern those areas of discourse where no possibility of agreement could possibly be reached. It contrasts Lyotard's notion of the differend with Habermas's of "consensus," and advances the argument that Lyotard's perspective not merely seems to be applicable to the global situation, today, but that it appears to be vindicated by the incommensurability of opinions, views and beliefs characterising the informational and communicational exchange in contemporary media on various aspects of the "pandemic." The latter include the question of the origin of the "novel coronavirus" (natural, zoonotic transfer to humans, or technoscientifically produced in a laboratory); the issue of so-called PCR-tests (reliable or not); whether to "lockdown" or not (Sweden versus the rest of the world); and perhaps the most vexing question of them all, namely, whether to receive a Covid-19 vaccine or not (one of several available ones), or to depend on alternative available treatments such as Ivermectin, when necessary. It is demonstrated that the available reports, opinions and pronouncements on these issues diverge irreconcilably, and therefore constitute an exemplary instance of the differend. Finally, the question is raised, what it would take to resolve the differend, or alternatively, make it disappear.

Keywords: Coronavirus; Covid; pandemic; differend; Lyotard

\section{UNISA $\cong$}




\section{Olivier}

The plaintiff lodges his or her complaint before the tribunal, the accused argues in such a way as to show the inanity of the accusation. Litigation takes place. I would like to call a differend [differend) the case where the plaintiff is divested of the means to argue and becomes for that reason a victim. If the addressor, the addressee, and the sense of the testimony are neutralized, everything takes place as if there were no damages.... A case of differend between two parties takes place when the "regulation" of the conflict that opposes them is done in the idiom of one of the parties while the wrong suffered by the other is not signified in that idiom (Jean-Francois Lyotard 1988: The Differend, 9).

\section{Introduction: The Differend}

Today, one is witnessing what could be a pivotal moment in the history of humankind. An ever-widening chasm is opening up between those people who obediently follow what their increasingly authoritarian governments instruct them to do, on the one hand, and those who, cognisant of the fact that governments, like all human institutions, are prone to failure of judgment, resist these attempts at governmental control in different ways, such as availing themselves of their constitutionally enshrined right to decide for themselves what to do in the face of an illness called a "pandemic." Has there ever been a moment in world history — at least during so-called peacetime - when the world's population has been as split on an issue of global importance as today, when what can truly be described as a Lyotardian differend (see below) obtains regarding the status of the coronavirus (Covid-19) "pandemic" and its attendant questions and problems? This is a rhetorical question, of course, but I am convinced that it probably applies to the current social reality, in a manner reminiscent of the notorious Yugoslav Wars fought between 1991 and 2001, which divided people in the former Yugoslavia bitterly along ethnic and religious lines. More recently, it is comparable to the irresolvable division among British citizens on the question of "Brexit" (which still persists five years after the Brexit vote; McGee 2021), and among American people during the presidency of Donald Trump, when one was either uncompromisingly pro-Trump or anti-Trump (Olivier 2020).

What I mean by saying that the current situation-pertaining to countervailing claims and questions about the so-called Covid-19 pandemic - instantiates what Lyotard characterises as a "differend" (I prefer to italicise this word to highlight it) is meant in precisely the manner that the French philosopher describes the eponymous "differend" in his book (Lyotard 1988, xi) as follows:

As distinguished from a litigation, a differend [différend] would be a case of conflict between (at least) two parties, that cannot be equitably resolved for lack of a rule of judgment applicable to both arguments. One side's legitimacy does not imply the other's lack of legitimacy. However, applying a single rule of judgment to both in order to settle their differend as though it were merely a litigation would wrong (at least) one of them (and both of them if neither side admits this rule).

This distinction, which clearly applies to the examples of Brexit and Trump's presidency, above (in neither case a "single rule of judgment" could be identified; 


\section{Olivier}

criteria of judgement were precisely what was at stake, and could not be determined or resolved), should be kept firmly in mind in what follows - although it should be noted that (as will be seen) the governmental responses to the "pandemic" (through lockdowns, for example) have much more serious implications for human rights and democracy than those which accompanied debates about Brexit and Trump. It should also be noted that Lyotard has explicitly rejected Jürgen Habermas's well-known criterion of "consensus" in interpersonal communication. Already in The Postmodern Condition (Lyotard 1984, 60), he noted:

...the principle of consensus as a criterion of validation seems to be inadequate. It has two formulations. In the first, consensus is an agreement between men, defined as knowing intellects and free wills, and is obtained through dialogue. This is the form elaborated by Habermas, but his conception is based on the validity of the narrative of emancipation.

Lyotard adds (1984, 60-61) that "In the second, consensus is a component of the system, which manipulates it in order to maintain and improve its performance. It is the object of administrative procedures ... In this case, its only validity is as an instrument to be used toward achieving the real goal, which is what legitimates the system-power." This is an important addition, but its implications - that consensus is often systemically "manipulated" in order to maintain power-while highly relevant to the present theme and time, cannot be pursued at length here because of space limitations. Suffice to say that it is an open question, when reviewing the opposing claims and arguments proffered by proponents of the two irreconcilable sides, whether one or both of them may indeed be guilty of systematically (and systemically) manipulating "consensus" for the sake of either maintaining or acquiring power. This will be revisited briefly towards the end of this paper.

Before proceeding further, it is worth noting Habermas's $(1990,100)$ observation, that:

... in reaching an understanding about something in the world, subjects engaged in communicative action orient themselves to validity claims, including assertoric and normative validity claims. This is why there is no form of sociocultural life that is not at least implicitly geared to maintaining communicative action by means of argument, be the actual form of argumentation ever so rudimentary and the institutionalization of discursive consensus building ever so inchoate. Once argumentation is conceived as a special form of rule-governed interaction, it reveals itself to be a reflective form of action oriented toward reaching an understanding.

One would perhaps want to agree with Habermas as far as his conviction is concerned, that all forms of "sociocultural life" are (at least implicitly) oriented towards "communicative action" (with its characteristic appeal to the mutual provision of validity claims for every party's respective statements), aimed at reaching consensus through "rational" discourse, and do not rather lean towards its contrary, namely "strategic action" (Habermas 1990, 58), where validity claims are either hidden or 


\section{Olivier}

distorted, to be able to gain power over others. However, the instances of incommensurable claims on both sides of the "pandemic divide," discussed below, raise serious questions about whether this is indeed the case (for both, or for one of the sides), or whether one is rather witnessing what Lyotard calls an irresolvable differend, as will be seen.

Perhaps some telling examples of a differend at the outset would enable one to ascertain more clearly that the current global situation represents a differend on a scale probably never before witnessed. Lyotard $(1988,3)$ elaborates on this as follows:

You are informed that human beings endowed with language were placed in a situation such that none of them is now able to tell about it. Most of them disappeared then, and the survivors rarely speak about it. When they do speak about it, their testimony bears only upon a minute part of this situation. How can you know that the situation itself existed? That it is not the fruit of your informant's imagination? Either the situation did not exist as such. Or else it did exist, in which case your informant's testimony is false, either because he or she should have disappeared, or else because he or she should remain silent, or else because, if he or she does speak, he or she can bear witness only to the particular experience he had, it remaining to be established whether this experience was a component of the situation in question.

Even without reading further, anyone with a modicum of knowledge about the Holocaust and what is known as the "historians" dispute" ("Historikerstreit" in German), would know that Lyotard is here alluding to the claim (that millions of Jews were exterminated by the Nazis during the Second World War, in the light of putative "evidence" such as extant gas chambers at places like Dachau and Auschwitz, and the verbal evidence of Holocaust survivors) - by certain historians - that this was in fact not the case, or at least that persuasive evidence to this effect does not exist in the shape of "victims," because the latter are all dead (Lyotard 1988, 3-14; Olivier 2021). This is why Lyotard states, above: "Or else it did exist, in which case your informant's testimony is false, either because he or she should have disappeared ..." etcetera. The claim (above) that "none of them is now able to tell about it" means, on the one hand, that those who were supposedly murdered in the gas chambers cannot, for obvious reasons, give evidence in this regard, and those who claim that they can indeed do so, are not acceptable as witnesses because "their testimony bears only upon a minute part of this situation"- that is, their experience in the concentration camps, and so on, but not of dying in the gas chambers.

This is a "genuine" differend, in so far as those who insist that the Holocaust did occur, appeal to "a rule of judgment" that allows the acceptance of the "evidence" of survivors (who were inmates in the concentration camps, and so on), while those who are equally insistent that there is no evidence of the Holocaust, point out that there is no survivor (that is, someone who "experienced" the gas chambers) who can testify to this fact. Clearly, the latter group require what the first group regard as a self-evident impossibility, that a deceased victim of the gas chambers give "evidence" of their having 


\section{Olivier}

perished there; nevertheless, the implicit "rule of judgment," however absurd it might appear to be, is different from, and irreconcilable with, that undergirding the one appealed to by the first group.

As a benevolent reviewer-critic has reminded me, more could be said here about the relevance of Lyotard's "victim" as one "divested of the means to argue," to illuminate the "current divisive context of the pandemic." Specifically, what does a "victim" look like under present pandemic conditions, given that McLennan (2018) claims that Lyotard's notion of the differend "... describes: a) the incommensurability of genres of discourse; b) the victimisation which occurs when one or more genres of discourse are rendered unintelligible or silenced by a dominant discourse"? What is meant by "victimisation" here becomes clearer in the light of what Lyotard $(1988,5)$ writes about a "wrong":

This is what a wrong ... would be: a damage ... accompanied by the loss of the means to prove the damage. This is the case if the victim is deprived of life, or of all his or her liberties, or of the freedom to make his or her ideas or opinions public, or simply of the right to testify to the damage, or even more simply if the testifying phrase is itself deprived of authority. ... In all of these cases, to the privation constituted by the damage there is added the impossibility of bringing it to the knowledge of others, and in particular to the knowledge of a tribunal.

In what follows the astonishing pertinence of these words for the present will become apparent, perhaps more tersely stated where Lyotard writes $(1988,9)$ : "I would like to call a differend ... the case where the plaintiff is divested of the means to argue and becomes for that reason a victim," which (as will be seen below) expresses the one side of what I here characterise as the current, global differend.

To clarify further, another, perhaps better-known instance of a (cultural) differend pertains to the contestation of land rights between Australian aborigines and development companies in Australia. What has become known as the "Mabo" High Court case in 1992 (McIntosh 1997), gave rise to legislation that has ensured the land rights of native Australians, but it has not succeeded in quelling simmering manifestations of the incommensurability (that is, a differend) between what developers want and what aboriginal peoples can now claim, namely the right to primary decisionmaking regarding their ancestral land. McIntosh (1997) formulates this situation succinctly:

It took over 200 years to achieve, and it is described as the single most important legal decision in Australian history. In 1992, Aboriginal and Torres Strait Islander native title property rights were recognized by the highest court in the land. In 1997, these rights are under threat. Mining companies and other developers assert that the Native Title Act 1993, enacted by the federal government, has given indigenous people too much power over development. They are insisting that the law be changed to reduce or annul most of the rights established by the court decision. 


\section{Olivier}

It does not require a genius to grasp the fact that this tension between what the aboriginal people have been granted by the court ruling, on the one hand, and what developers want, on the other hand, instantiates an exemplary instance of a differend, given the obvious divergence between the respective "rules of judgement" underpinning either position. The claims of the indigenous people to their land-occupied long before Western settlers arrived there-rest on a set of values that centre on, for example, the sanctity of ancestral burial sites and the like, while those of the developers rest on capitalist principles of profit-seeking that cannot accommodate the values attached to the land by the aborigines.

Keeping in mind that the cultural-historical differend pertaining to the situation, above, differs from that emanating from the "pandemic," in so far as the former plays itself out in the historical, cultural and legal arena, while the differend attendant upon the "pandemic" arguably bears precisely on the question that is presupposed by any claim to legal recourse, namely that of human rights as enshrined in the Universal Declaration of Human Rights of the United Nations (1948), and in the constitutions of many countries. It is in this sense that I intend to show that a demonstrable differend functions in the discursive arena where mutually antagonistic claims or sites of contestation regarding the current "pandemic" are located, including: whether it really is a "pandemic" (which is why I put the term "pandemic" in scare quotes); questions pertaining to the origin of the "novel coronavirus"; the so-called PCR-tests; the justifiability of "lockdowns"; and perhaps most vexing, the issue of the so-called "vaccines." Although I shall not elaborate on the issue, it should be noted that it is the last three of these "sites" that highlight the pertinence of questions concerning human rights.

\section{Is it a Pandemic?}

Before scrutinising the sites of contestation where the differend is most conspicuous, a brief look at the question, whether the world is really facing a "pandemic," is necessary. To those people who simply accept at face value what the mainstream sources of information dish up about the current coronavirus crisis in the world, there is no doubt that humanity finds itself in the middle of a "pandemic," given the routine usage of the term. For example, on the World Health Organisation's homepage the words, "Emergency_Coronavirus disease (Covid-19) pandemic" are prominently displayed against a bright pink backdrop in the top left-hand corner, and all the various categories organising information on the website have to be seen in this light. Furthermore, every major news outlet, such as CNN, BBC, Fox News, RT, and so on, all employ the term "pandemic" in relation to the coronavirus situation globally. It is worth noting that the Merriam-Webster Online Dictionary (see details under References) distinguishes between an epidemic and a pandemic in the following manner:

An epidemic is defined as "an outbreak of disease that spreads quickly and affects many individuals at the same time." A pandemic is a type of epidemic (one with greater range and coverage), an outbreak of a disease that occurs over a wide geographic area 


\section{Olivier}

and affects an exceptionally high proportion of the population. While a pandemic may be characterized as a type of epidemic, you would not say that an epidemic is a type of pandemic.

In these terms it appears to be justifiable to talk about the Covid-19 "pandemic," therefore. To introduce the idea of a differend as far as this is concerned, one might argue that it is not sufficient to state that a disease "affects an exceptionally high proportion of the population," unless it is made clear what "affects" really means. So, to problematise such a definition, a contrary position might claim that, to determine whether it really is a "pandemic," the first thing to do is to look at some of the agencies that track its "progress" at various levels - total cases, total deaths (in relation to number of "cases"), deaths per one million of the population and so on. When this is used as a "rule of judgement," instead of "affecting an exceptionally high proportion of the population," a different picture emerges. In fact, then it is difficult not to come to the conclusion that this is not, strictly speaking, a "pandemic"-that is, if one judges in terms of the number of fatalities (assuming these are all directly related to Covid-19).

Looking at one of the best-known websites among these agencies, "WorldometerCoronavirus Update," one will notice something crucial. It is not so much the number of cases, or even the total number of deaths that is most informative; the really significant item is "Deaths $1 \mathrm{M}$ pop" (deaths per one million of the population), pertaining to the world's total population of more than 7.5-billion people. The figure is also indicated for every country, and is interesting in its own right, but it is the total deaths per million of the world's population that is most significant. Today (30 June 2021) it stands at 507.5 deaths per million of the world's population. Mathematically speaking, that works out to $0.05075 \%$ of people who have died (supposedly because of the virus) in relation to the total population of all countries combined. Put differently, to date more than $99.9 \%$ of people have survived this dreaded disease. The relevant part of this information is that Covid-19 displays high contagion, combined with a very low mortality rate, which anyone can check on the Worldometer website.

\section{The Covid-19 "Pandemic": The Origin of the "Novel Coronavirus"}

It is difficult (if not impossible) to describe, or reconstruct, the Covid-19 "pandemic" dispassionately, and I put this term in scare quotes because it is what is fundamentally contested, without any possibility of agreement in sight at this historical stage (June/July 2021). The SARS-CoV-2 virus is one of a cluster of sub-microscopic entities with ribonucleic acid (RNA) as their genetic material (Astuti and Ysrafil 2020). This microscopic viral living entity normally plays the role of a messenger that carries instructions, or information, from deoxyribonucleic acid (DNA) for the regulation of protein-synthesis as a process. This is reminiscent of digital online viruses that can similarly be seen as "messengers" carrying damaging information to their identified goals, such as military computer banks, private computer files or bank accounts. While these digital viruses inhabiting the internet are programmed to find ways of getting into 


\section{Olivier}

their target files, so, too, the viral RNA of the so-called "novel coronavirus" (SARSCoV-2) utilises a disguise that mimics the RNA produced by human DNA to enter the protein-synthesis mechanism of human bodies.

There are several accounts regarding the emergence of the coronavirus. Until recently, most virology research claimed that it probably first appeared at a wet market in Wuhan, China, as a result of "zoonotic" transfer from an animal (a bat or a pangolin, for instance) to humans. This is estimated to have occurred towards the end of 2019, subsequently rapidly infecting people in the area through contact and proximity, before being carried from there throughout the world on and in the bodies of human hosts on aeroplanes (mostly without their knowledge). Yet, even by March 2020, confirmed in May (Woodward 2020), indications started emerging that "Scientists are still unsure where the virus originated, and will only be able to prove its source if they isolate a live virus in a suspected species - a hard task" (Walsh and Cotovio 2020). By June 2021, scientists still claim that the exact animal origins of the coronavirus are unknown because of the complexity of the process of tracing it (Johnson 2021). Furthermore, Walsh and Cotovio (2020), together with a host of other sources (e.g., Carrington 2020), have emphasised that, according to zoologists and disease experts it is the destruction of the natural habitats of animals, together with the stress it causes on the part of affected species, that is at the basis of such "zoonotic spillover" of viruses from animals to humans. In brief: animals may be the proximate "source" of the novel coronavirus, but humans have created the conditions for this to happen - an unmistakeable indictment of human environmental destruction (Olivier 2020a). Regardless of the differences of opinion among scientists concerning the precise mechanism of emergence and source of the novel coronavirus, however, the prevailing view today is still that it is of "natural" origin, and in the language of the differend one can say that the "rule of judgement" (that is, the principle on which scientific claims are based) in this case pertains to known processes of "zoonotic spillover" or transfer of pathogens from animals to humans (Johnson 2021).

This is only one side of the story, as the saying goes, however. In recent days (June 2021) another account, which has long been latent but was labelled a "conspiracy theory," has been given more credence by several events - the claim that the novel coronavirus was intentionally "engineered" in a laboratory at the Wuhan Institute of Virology in China. Here one faces a completely different "rule of judgement," namely the assumption that the virus is not the product of "natural" evolution, and was not accidentally transferred to humans at a so-called "wet market" where wild animals are routinely sold for food, but was deliberately constructed by means of genetic manipulation in a laboratory. Needless to stress, these two "rules of judgement" are incompatible, and a differend therefore emerges.

But what, precisely, does the latter claim - that of a laboratory origin of the coronavirus - amount to? Contrary to the natural origin hypothesis (and as stated above), it claims that the coronavirus was the result of genetic manipulation of a 


\section{Olivier}

coronavirus in a laboratory, specifically at the Wuhan institute of Virology. In this regard Maxman and Mallapaty (2021) write:

Scientists don't have enough evidence about the origins of SARS-CoV-2 to rule out the lab-leak hypothesis, or to prove the alternative - that the virus has a natural origin. Many infectious-disease researchers agree that the most probable scenario is that the virus evolved naturally and spread from a bat either directly to a person or through an intermediate animal.

Maxman and Mallapaty (2021) also remind one that "Debate over the idea that the SARS-CoV-2 coronavirus emerged from a laboratory has escalated over the past few weeks ..." What they do not say, although there is a cursory reference to him, is that $\mathrm{Dr}$ Anthony Fauci, the Director of the National Institute of Allergy and Infectious Diseases in the United States, recently (May 2021) became the centre of a storm of controversy worldwide when a trove of his e-mail messages from the first half of 2020 was made public. BBC News (2021) reports as follows:

A January 2020 email to Dr Fauci from the director of the country's largest biomedical research facility suggested the "unusual features" of the virus may indicate it is "engineered," prompting Dr Fauci to say he will reach out via phone.

In April 2020, an email from the director of the National Institute of Health, Francis Collins, nudged Dr Fauci with the subject line "conspiracy gains momentum." The doctor's response to this is fully redacted.

This May, Dr Fauci said he is "not convinced" the virus originated naturally and expressed support for an investigation.

Apart from the fact that the redaction of Fauci's response on the suggestion that the "conspiracy" was gaining traction has exacerbated the controversy, with many commentators - including US Senator Rand Paul (Guterl 2021) — calling for a thorough investigation of Fauci's involvement, through funding, in so-called "gain-of-function" research regarding viruses at the Wuhan institute, his own support of an investigation into the possibility that the virus was engineered highlights the differend that one faces here. This differend concerns the incommensurability of the respective, underlying "rules of judgement": the natural-origin hypothesis accepts that the novel coronavirus is of natural evolutionary origin, even while admitting the difficulty of tracing its provenance, while the laboratory-origin hypothesis is based on the claim that it is the result of intentional genetic manipulation of a coronavirus, possibly (if not probably) with dubious purposes (such as deliberately starting an epidemic). Again, it is a differend because these two hypotheses are irreconcilable - a mediating "rule of judgement" that would lead to "consensus" is impossible to find. Except-as I argue towards the end of this paper-if something were to happen (an event of decisive import) that would invalidate the "rule of judgement" of one of these two sides. 


\section{Olivier}

It may just be that something of this magnitude has just emerged (The Truth Hunter 2021) — on 12 July 2021, through a friend, I discovered a long interview, conducted by lawyer Dr Reiner Fuellmich (referred to again below) with Dr Dave Martin, CEO of a company that works with, and therefore has regular access to, all the patents in the US Patent Office (therefore in the public domain), and who painstakingly unravels the history of the "novel" coronavirus as not being novel at all, but as something that was "patented" in various, slightly differing formats, more than 70 times before it was "released" into the world. The motive? According to Dr Martin, it seems that it was financial profit from the vaccines, some of which, astonishingly, were developed before the "outbreak" of the "pandemic." Needless to emphasise, if all of this evidence were to be presented in a court of law, it may just tilt the balance towards the side of the global split that I here call the "resistance" to the "official narrative" (more on this below). There are so many sides to this wide-ranging interview that it would take a separate study to cover it all; suffice to say at present that anyone interested in this should listen carefully to this interview (The Truth Hunter 2021), because it promises to be of decisive importance.

\section{PCR Tests}

The so-called "PCR tests" (see WHO PCR-tests under References)—which are used to determine whether one has been infected by the novel coronavirus - are pivotal to understand the gravity of the differend that characterises the global informational field as well as the countervailing discourses within this field. Why is that? It is because at their extremes, the opposing claims regarding these tests (which are routinely used to determine whether a person has been "infected" by the SARS-CoV-2 virus) are sufficiently far removed from one another that, by implication, they assert conditions of legitimacy and of complete illegitimacy, respectively, as far as the actions recommended by the WHO and other health-oriented institutions, as well as the consequent measures taken by governments are concerned. In what follows I have chosen not to abridge or paraphrase the scientifically oriented excerpts from various documents, allowing them to speak for themselves instead, so that readers can get a thorough grasp of what is at stake. I have, however, framed and interpreted these excerpts in terms of the theme of this paper.

What is a PCR-test? The acronym stands for "polymerase chain reaction" and it was invented by Dr Kary Mullis in 1985, which earned him the Nobel Prize for Chemistry in 1993. The test allegedly enables one to detect, among other things, the presence of a virus in a human body, not by isolating the virus (see Racaniello 2020), but by amplifying the genetic material of a virus in the body up to a level where it can be detected or "seen" (Reuters Staff 2020; see also Jawerth 2020). It is important to note the following, however (Reuters Staff 2020):

A spokesperson for Public Health England told Reuters why PCR tests are being used widely in England: "Molecular diagnostic tests, such as real-time PCR, are the gold standard methods for identifying individuals with an active viral infection, such as 


\section{Olivier}

SARS-CoV-2 (the cause of Covid-19 disease), in their respiratory tract. These tests are rapid and produce results in real-time.

It is important to note that detecting viral material by PCR does not indicate that the virus is fully intact and infectious, i.e. able to cause infection in other people. The isolation of infectious virus from positive individuals requires virus culture methods. These methods can only be conducted in laboratories with specialist containment facilities and are time consuming and complex.

Hence, while the PCR-test is regarded as the "gold standard" method for determining whether a person has been infected by the SARS-CoV-2 virus, health officials admit that it does have its limits in not confirming the full presence of the virus, nor the "infected" person's capacity to infect other people.

The first person to make successful use, together with specialists in his laboratory, of Dr Mullis's invention, the PCR-test, for the diagnosis of the SARS-CoV-2 virus in people early in 2020, was Dr Christian Drosten, who had also been the first to develop a test for diagnosing SARS-CoV in 2003. This is how it was reported in Science (Kupferschmidt 2020):

After seeing the first rumors about a coronavirus in China online, Victor Corman, who leads the [Dr Drosten's; B.O.] lab's virus diagnostics group, began to search existing sequences of SARS-related coronaviruses, isolated from bats, for regions that were the same across different viruses. He was trying to guess what parts of a new SARS-like coronavirus might look like, in order to create a test. Based on those sequences, he designed and ordered 20 pairs of so-called primers, little snippets of DNA, that pair with a pathogen's genome, so that it can be amplified and detected.

When Chinese researchers finally published the genome of the new virus from Wuhan on 10 January, Corman used the primers that best matched the viral sequence and prepared the diagnostic test almost immediately. WHO posted Corman's protocol on its website on 13 January, allowing countries around the world to produce a test themselves and detect imported cases of the new virus. Drosten predicted the test would also help scientists understand whether the virus was able to spread from human to human.

Drosten has since become famous, not only in his native Germany, but worldwide, for his role in developing a PCR-test to identify people infected with the novel coronavirus. However - and this is where the differend under discussion rears its head regarding the role of the PCR-test in the context of the Covid-19 "pandemic" - not everyone agrees that it is a reliable method for ascertaining the number of people infected with the virus. In fact, the growing worldwide opposition to government measures, such as lockdowns, also concerns the allegedly flawed way that the PCR-tests are conducted, namely in a manner that renders a high percentage of what are called "false positives." For instance, Dr Reiner Fuellmich (Fuellmich 2021; see also "Fuellmich" under References) —a German and American lawyer who, together with the "Corona Investigative Committee," is leading an international global investigation into the Covid-19 


\section{Olivier}

"crisis"- points out that when material from a swab used to gather a specimen from a person's nasal cavity is accelerated at or above 24 cycles (to amplify the genetic material present in an effort to trace evidence of the coronavirus), it is no longer reliable, and produces "false positives." If this is the case, the result has been that the number of infections worldwide is grossly exaggerated, and it is noted that these are used as a means to instil fear in countries' citizens, which makes them so much easier to manipulate. This point, concerning the "false positives" that PCR-tests yield when amplification cycles above 24 are (routinely) used, has been emphasised by Dr Sam White (O'Sullivan 2021), a British medical doctor who recently charged the NHS in Britain with misconduct regarding the treatment of patients with Covid-19 as well as regarding the promotion of "vaccines" that are not really vaccines, but "genetic manipulation" (more about the "vaccines" below).

Regarding the reliability of the PCR-test for Covid-19, it is also notable that in November, 2020, The Portugal News (2020) reported that:

The PCR test "is unable to determine, beyond reasonable doubt, that a positive result corresponds, in fact, to the infection of a person by the SARS-CoV-2 virus," said the Lisbon Court of Appeal.

This verdict was underscored by the fact that the judges had taken the authoritative opinion of scientists into consideration, which has to be quoted here in full (The Portugal News 2020):

The judges quoted a paper published in The Lancet by Elena Surkova, Vladyslav Nikolayevskyy and Francis Drobniewski, which stated: "Any diagnostic test result should be interpreted in the context of the pretest probability of disease. For Covid-19, the pretest probability assessment includes symptoms, previous medical history of Covid-19 or presence of antibodies, any potential exposure to Covid-19, and likelihood of an alternative diagnosis. When low pretest probability exists, positive results should be interpreted with caution and a second specimen tested for confirmation."

The paper continues: "Prolonged viral RNA shedding, which is known to last for weeks after recovery, can be a potential reason for positive swab tests in those previously exposed to SARS-CoV-2. However, importantly, no data suggests that detection of low levels of viral RNA by RT-PCR equates with infectivity unless infectious virus particles have been confirmed with laboratory culture based methods."

To summarise, false-positive Covid-19 swab test results might be increasingly likely in the current epidemiological climate in the UK, with substantial consequences at the personal, health system, and societal levels (panel).

With this verdict in mind, it is unsurprising that, very recently (23 June 2021), America's Frontline Doctors - an organisation that consistently questions the "mainstream" approach to the "pandemic," in this way marking the differend in question-also posted a report (Sones/America's Frontline Doctors 2021) on the fact that the Lisbon court was 


\section{Olivier}

obliged, in light of a citizens' petition, to supply verified data on actual Covid-19 mortality rates in Portugal. The court's ruling stated that verified deaths from January 2020 until April 2021 amounted to 152, and not approximately 17 000, as claimed by the relevant government department. The others died for different reasons, although their PCR-tests were indicated as positive. Andre Dias, on whose investigation the Sones report is based, made the following pertinent observation (quoted in Sones/America's Frontline Doctors 2021): "If these figures are of the same order of magnitude for other countries as well, and there is no reason to assume otherwise, then the plague is a deception of unprecedented proportions and crimes ... against humanity on a huge scale have been committed here." The differend in question can hardly appear more starkly than here. On the one hand, there are the agencies which claim that the PCR-tests assist medical personnel in identifying people infected with the coronavirus in order to treat them; on the other hand, there are those that point to evidence that these tests lead to "false positives," and that massive deception is therefore involved.

Another researcher who questions the accuracy and therefore the validity of the Covid19 PCR-tests is Michel Chossudovsky (2021), a Canadian economist, who is described as a "conspiracy theorist" by those on the other side of the differend-divide. In his freely available e-book, The 2020-21 Worldwide Corona Crisis: Destroying Civil Society, Engineered Economic Depression, Global Coup d'État and the "Great Reset," Chossudovsky draws attention to "official definitions and procedures" pertaining to these tests "which are contradictory" (2021, Chapter 3; note that "CDC" refers to the United States Centers for Disease Control and Prevention; I quote at length; bold in original):

"The Covid-19 RT-PCR test is a real-time reverse transcription polymerase chain reaction (rRT-PCR) test for the qualitative detection of nucleic acid from SARS-CoV2 in upper and lower respiratory specimens ... collected from individuals suspected of Covid-19 ... [as well as] from individuals without symptoms or other reasons to suspect Covid-19 infection ...

This test is also for use with individual nasal swab specimens that are self-collected using the Pixel by LabCorp Covid-19 test home collection kit ... The Covid-19 RT-PCR test is also for the qualitative detection of nucleic acid from the SARS-CoV-2 in pooled samples, using a matrix pooling strategy (FDA, LabCorp Laboratory Test Number: 139900) ...

This test is based on upper and lower respiratory specimens. The criteria and guidelines confirmed by the CDC pertaining to "The CDC 2019-Novel Coronavirus (2019-nCoV) Diagnostic Panel" are as follows (Read carefully):

Results are for the identification of 2019-nCoV RNA. The 2019-nCoV RNA is generally detectable in upper and lower respiratory specimens during infection. Positive results are indicative of active infection with 2019-nCoV but do not rule out bacterial infection or co-infection with other viruses. The agent detected may not 


\section{Olivier}

be the definite cause of disease. Laboratories within the United States and its territories are required to report all positive results to the appropriate public health authorities.

Negative results do not preclude 2019-nCoV infection and should not be used as the sole basis for treatment or other patient management decisions. Negative results must be combined with clinical observations, patient history, and epidemiological information.

What this suggests is that a positive infection could be the result of co-infection with other viruses. According to the CDC it "does not rule out bacterial infection or coinfection with other viruses. The agent detected may not be the definite cause of disease." (CDC 2020)

All that is required is the presence of "viral genetic material" for it to be categorized as "positive." The procedure does not identify or isolate Covid-19. What appears in the tests are fragments of the virus.

The last three paragraphs, especially, demonstrate the contradictory nature of these official definitions - a positive result of a PCR-test for Covid-19 need not actually be accurate - it could betray the infection or co-infection with other viruses. Furthermore, a positive result indicates the detection of genetic "material," which could be in the guise of mere "fragments." It should be abundantly clear that the PCR-tests used for detecting infection by the novel coronavirus comprise a discursive marker or terrain indexing an irresolvable differend in Lyotard's sense of the term.

To conclude this section, in the work of David Pittaway (2020) one encounters a radical questioning of the numbers associated with PCR-testing. In an article tellingly titled "Coronavirus, meaningless numbers, disaster capitalism: Oligarchy's dream come true," and drawing on the work of well-known researcher, John Ioannides, Pittaway (2020) states:

Have you wondered about the relevance of coronavirus test results? If you did, you would have been thinking similarly to the esteemed Stanford professor, John Ioannidis. He wrote an article with a title worth a thousand words: "A fiasco in the making? As the coronavirus pandemic takes hold, we are making decisions without reliable data." In the article, Ioannidis states that reported "case fatality rates, like the official $3.4 \%$ rate from the World Health Organisation [WHO], cause horror-and are meaningless."

One of the reasons Ioannidis takes issue with reported case fatality rates is that many of the numbers in the mainstream media provide information that is only relevant in the context of the total number of tests carried out. The total number of people who actually have the virus will certainly be much bigger than the number confirmed by testing. As Ioannidis states, "We don't know if we are failing to capture infections by a factor of three or 300." One can only claim a death rate if one knows exactly how many people in a population have the virus. Nobody knows the overall number, but early antibodies testing suggests that it is considerably large - much larger than the numbers arrived at from counting RT-PCR (Jawerth 2020) tests. 


\section{Olivier}

From this excerpt it should be evident that reliance on PCR-test results is far from unproblematical, at least to some researchers, even if the WHO- on the other side of the differend-divide - seems to regard it as self-evidently reliable. There should be no doubt, however, that (from the perspective of what might be termed "the resistance" to the mainstream pandemic narrative) what is argued to be "faulty" PCR-tests comprises the very (questionable) basis of claiming that there is a "pandemic." As Dr Reiner Fuellmich, the international lawyer (referred to earlier) leading the investigations into the origin and development of the "pandemic," observes in a recent interview, this means that it is really not a coronavirus pandemic, but a "PCR-test pandemic" (Fuellmich 2021a). As briefly mentioned above, this was confirmed recently when a Portuguese court in Lisbon ruled that between January 2020 and April 2021 only $0.9 \%$ (152) of the supposed deaths from Covid-19 were actually authentic; the rest of the approximately 17000 deaths were from other causes, even though the deceased tested "positive" for Covid-19 (Sones/America's Frontline Doctors 2021).

However, representatives of the official narrative do not hesitate to challenge claims concerning the inaccuracy of the PCR-tests. So, for example, a statement by the World Doctors Alliance (2021), that there is no global pandemic and that $89 \%$ to $94 \%$ of PCRtests are "false positives" is repudiated in a report by Health Feedback (2020) by calling such a claim, which "could be interpreted in different ways," "vague." It avoids focusing on what was discussed earlier regarding the appropriate number of "cycles" to use in a PCR-test, as well as the "contradiction" that Chossudovsky (2021) has identified in the CDC definitions and procedures (discussed above).

As a kind of postscript, one should add that, since I first wrote this article, the CDC (2021a) has issued the following statement on their website:

After December 31, 2021, CDC will withdraw the request to the U.S. Food and Drug Administration (FDA) for Emergency Use Authorization (EUA) of the CDC 2019Novel Coronavirus (2019-nCoV) Real-Time RT-PCR Diagnostic Panel, the assay first introduced in February 2020 for detection of SARS-CoV-2 only.

Whether this statement constitutes a tacit admission, on the part of the CDC, of the PCRtest's irremediable unreliability, I leave to readers to decide.

\section{Lockdowns}

It is only too well known to virtually everyone in the world today that one of the measures (putatively) against the spread of the coronavirus is what is known as a "lockdown"- not in the sense of locking prisoners in their cells for a specific period of time for security (which is one meaning of the word), but as a (putatively) temporary measure where people are required by governments to stay in their homes, or avoid contact with others by engaging in limited activities during an epidemic to prevent the spread of the disease (Reuters Staff 2. 2020). It is also a well-known fact that, soon after the outbreak of what was later called Covid-19 in Wuhan (China), the Chinese 


\section{Olivier}

authorities imposed strict lockdown measures, accompanied by (controversial) "pandemic protocols" such as face mask-wearing and "social distancing" (SolisMoreira 2020) to limit the outbreak. (The latter two "protocols" will not be discussed here in detail because of space restrictions.) Many other countries followed suit as the virus spread across the world, carried by unwitting passengers on international flights, for example. But the question remains: Are lockdowns as effective as they are claimed or believed to be, given the obvious economic and psychological effects accompanying them? It is not difficult to locate a Lyotardian differend at the heart of the diametrically opposed, different claims regarding lockdowns. So, to state the mainstream position first (in a clearly articulated manner), while admitting that lockdowns can have deleterious economic, social and psychological consequences for (particularly vulnerable) people's lives, Reuters (Reuters Staff 2. 2020) claims that its "fact-checking" has revealed lockdowns to have, on the whole, a salutary effect in terms of both economic recovery and health. It is stated that:

Reuters has reported on international studies that have determined that lockdowns potentially have saved millions of lives ...

But evidence also suggests that stringent but temporary restrictions, could actually benefit the economic recovery because they reduce the spread of the disease. The International Monetary Fund, for example, determined ... that while lockdowns "impose short-term costs" they may lead to "a faster economic recovery." The organization states that "by bringing infections under control, lockdowns may thus pave the way to a faster economic recovery as people feel more comfortable about resuming normal activities" ...

Reuters contacted two experts, Dr. Elizabeth Stuart, Associate Dean for Education at the Johns Hopkins Bloomberg School of Public Health ... and Dr. Stuart Ray, infectious disease expert with the Johns Hopkins University School of Medicine.... Both confirmed that lockdowns do reduce transmission of the SARS-Cov-2 and highlighted that a more "targeted" or "proportional" approach of restrictions can mitigate the risk of infection, while balancing other concerns about the economy and mental health.

As might be expected, The Vaccine Alliance (GAVI 2020) adopts the same position on lockdowns. While similarly granting that lockdowns have caused significant "collateral damage to the global economy" it justifies lockdowns by making observations such as this:

Several countries, such as China, Germany and Spain, noted a fall in infections after lockdown measures were implemented. A study in China showed that the time for the number of cases to double rose from 2 days to 4 days, indicating a slowing down in transmission. Researchers estimate that the five-week lockdown in Italy prevented 200,000 hospital admissions from Covid-19 and reduced transmission of the virus by $45 \%$. 


\section{Olivier}

From these two representative examples of the mainstream position regarding all aspects of the "pandemic," it is beyond doubt that, despite recognising the deleterious consequences for countries' economies and human lives (in the guise of negative psychological effects, for example), lockdowns are regarded as justifiable because of their putative ameliorating effect on the spread of the coronavirus and accompanying hospitalisation of patients. When comparing this "official" position, supported by reference to several studies on the Reuters and GAVI websites, to the adversarial position (that of the "resistance" to the official narrative), the differend, which is the theme of the present paper, announces itself unmistakeably. To focus on a study that articulates the alternative perspective on lockdowns clearly and thoroughly, Professor of Public Health, Eyhal Shahar (2021), has published a commentary significantly titled "Not a shred of doubt: Sweden was right." Alluding to the counting of the dead during an epidemic (the task of epidemiology), Shahar (2021) remarks that, today:

The most counted country is probably Sweden, a stubborn dissenter that refused lockdowns, mask mandates and contact tracing. By the time of this writing, 14,349 Swedes have reportedly died from the coronavirus. Has the Swedish model failed? Were the lockdowns justified? Were the economic and social upheavals in most of the world an unavoidable necessity?

The answer to all is a resounding no. The first (and not the only) witness: Sweden.

To substantiate his argument, Shahar (2021) adduces several charts that compare the deaths in what he terms a "flu [influenza] year" with the deaths during the current "pandemic." The charts show that, since 1999, there has been a steady decline in flu deaths in Sweden, with slight ups and downs from one year to the next. The most relevant figure concerning the question, whether Sweden's avoidance of lockdowns yielded fruit, or alternatively, a far larger number of mortalities, is the figure for 20192020 (the "pandemic year"), namely 364 deaths per million (of the population) more than the expected number (which is calculated according to the average number of deaths since 1999, represented by a straight, descending line drawn through the various figures. Shahar (2021) draws attention to the fact that deviations from this straight line represent either "excess mortality" (if there are more deaths than the average) or alternatively "deficit mortality," which are numbers that usually alternate because of an aging population (like the Swedish): "Excess mortality following mortality deficit, and vice versa, are well known and expected, as the main source of mortality is an elderly population with limited life expectancy." That is (assuming I understand Shahar correctly), if there is an "excess" in mortality rates in one year, the next year usually displays a "deficit," because the year after the latter witnesses deaths on the part of those who are the previous "excess" year's survivors, who are then two years older and therefore tip the scales towards "excess" compared to the expected average. He then comes to the following important conclusion (Shahar 2021):

Assuming the excess mortality in 2019-2020 "fully balanced" the mortality deficit in the previous flu year, the true excess mortality in Sweden was less than 1\% (about 700 


\section{Olivier}

deaths). And if we assume, absurdly, that the mortality in 2019-2020 was not affected at all by the mortality deficit in the previous flu year, then the excess mortality in Sweden did not exceed $4.1 \%$ (about 3,800 deaths). Excess mortality of a few percentage points, or more, has been calculated in many countries where life has been severely disrupted. Part of that excess has been attributed to lockdown and panic.

To remind us, the hysterical response to the pandemic was not due to fear of an excess annual mortality of $4 \%$ or even $10 \%$. The apocalyptic forecasts, which caused the world to shut down, predicted about 90,000 deaths from the coronavirus in Sweden by the summer of 2020: $100 \%$ excess mortality! No wonder policy makers around the world prefer to forget those predictions.

If one considers that the "excess mortality" figures for 2019-2020 do not take any possible deaths from flu into consideration-Shahar (2021) remarks, with heavy irony, that "the coronavirus replaced the flu viruses this year, and there was no flu in Sweden, either" - then it should be clear that Sweden's rejection of the lockdown option did not have any significant impact on the "Covid-19" mortality rates in that country during the period scrutinised. Shahar's (2021) concluding paragraph is paradigmatic of the "resistance" position regarding the pandemic, specifically regarding lockdowns:

The pandemic has taken its death toll, ranging from large to small in different countries and within countries, and mostly affected the frail elderly. But the lockdowns and panic were unsubstantiated, prevented nothing, and caused indescribable damage to society. Sweden's statistics tell us, unequivocally, that in much of the world lives have been lost and livelihoods have been destroyed-in vain.

The question concerning lockdowns, particularly in light of Sweden's choice in this regard, has received a lot of attention worldwide. As a random example one might take the report on the mainstream news site, $\mathrm{CNN}$, titled: "Sweden challenges Trump —and scientific mainstream - by refusing to lock down" (Lister and Shukla 2020), where it is reported that:

Sweden's actions are about encouraging and recommending, not compulsion. Two days after Spain imposed a nationwide lockdown on March 14 [2020], Swedish authorities were encouraging people to wash hands and stay at home if sick. On March 24, new rules were introduced to avoid crowding at restaurants. But they very much stayed open.

As might be expected, this did not sit well with the mainstream. Small wonder that Lister and Shukla (2020) further report that:

The World Health Organization (WHO) is skeptical of Sweden's approach. Noting a fresh surge in the country's infections, the WHO told CNN Wednesday that it's "imperative" that Sweden "increase measures to control the spread of the virus, prepare and increase the capacity of the health system to cope, ensure physical distancing and communicate the why and how of all measures to the population." 


\section{Olivier}

Anyone who has familiarised him- or herself with Lyotard's notion of a differend would notice the irreconcilable difference between the perspective of the WHO and that of Shahar (2021), elaborated on above. To grasp the gravity of the present situation, where such incommensurability of judgement can and does occur, one should remind oneself of Lyotard's uncompromising characterisation of a differend (Lyotard 1988, 9):

A case of differend between two parties takes place when the "regulation" of the conflict that opposes them is done in the idiom of one of the parties while the wrong suffered by the other is not signified in that idiom.

I shall leave it to readers to decide which "idiom" it is, in the current global "pandemic" situation, that is employed to "regulate" the divergence, if not conflict, between the two "parties" concerned - the one espousing the "official" version, or the one representing the "resistance" in this context.

\section{Interlude: Two well-known Experiments on Obedience}

To make sense of the apparent ease with which governments have been able to impose lockdowns on citizens, one can approach the question of "lockdowns" during the "pandemic" from the perspective opened up by the question of "obedience." It appears that the tendency to obey orders is deep-rooted in people, judging by the results of two infamous experiments carried out by social scientists in the 20th century. The first was the "Milgram shock experiment" (McLeod 2017), named after Dr Stanley Milgram, and was conducted at Yale University in 1962. The second, similar experiment was performed by his erstwhile classmate, Dr Phillip Zimbardo, at Stanford University in 1971 and is known as "The Stanford prison experiment" (McLeod 2020), on which a feature film is based. Zimbardo decided to carry out the Stanford prison experiment because he wanted to explore further, in situational terms, what had been uncovered by Milgram nine years earlier, when the latter set out to test the limits of obedience to authority figures on the part of participants. In the Milgram experiment, the participants, who were labelled the "teachers," were given the command to administer electric shocks of increasing voltage to a male "student"-who was really, unbeknown to the participants, an actor-whenever he gave incorrect answers to questions.

The alarming thing about the experiment was that the participants obeyed the instructions, given by the authority figure present, to apply the painful shocks, even when the "student" complained, or pleaded with them to stop administering them, and even when they showed signs of reluctance to continue doing so. In the Zimbardo experiment volunteers were selected from undergraduate students and these were divided into "prisoners" and "guards," while Zimbardo acted as "warden." The "prisoners" were confined to makeshift "cells" in groups of three, with beds and all, and the "guards" were given eight-hour guarding sessions. The psychological effects of this prison environment-simulating experiment were remarkable: those students assigned the role of guards identified so much with their positions and the power it gave them that they became increasingly abusive towards the "prisoners." Just how much the 


\section{Olivier}

simulated prisoner-warden situation, where complete obedience was expected from "prisoners," affected the volunteers in both groups is evident from McLeod's (2020) remark, that:

As the prisoners became more dependent, the guards became more derisive towards them. They held the prisoners in contempt and let the prisoners know it. As the guards' contempt for them grew, the prisoners became more submissive.

As the prisoners became more submissive, the guards became more aggressive and assertive. They demanded ever greater obedience from the prisoners. The prisoners were dependent on the guards for everything so tried to find ways to please the guards, such as telling tales on fellow prisoners.

The latter increasingly showed all the signs - stress, extreme anxiety and depressionof people who felt helpless in the face of intransigent authority. The result was that the experiment, which had been planned to last for two weeks, had to be terminated after only six days. What one seems to be able to infer from this is that, when one receives instructions from someone in authority to perform certain actions, regardless of how unacceptable these seem to the one receiving the commands, one is likely to carry them out because the responsibility seems to be transferred to the one(s) who issued them. It is significant that these experiments were carried out soon after the widely publicised trial of notorious war criminal, Adolf Eichmann, who had been responsible for the death of thousands of Jews in a concentration camp, and who defended his actions by claiming that he had merely been doing his job-carrying out orders from higher authorities (Berenbaum 2021).

My reason for recounting these two highly revealing social-psychology experiments, is the impression that, during the "pandemic," one has been witnessing a massive global repetition of the Milgram and Zimbardo experiments, with people in virtually every country showing all the familiar signs of obedience to authority, even when these authorities ride roughshod over the civil rights embedded in the constitutions of (probably) most countries. The flipside of this tendency are the signs that governments have become increasingly authoritarian - that is, rigidly controlling the behaviour of citizens. Here in South Africa, governmental responses to the pandemic are not presented as guidelines, however, but as rules and restrictions, if not "emergency laws" which, for all intents and purposes, suspend the country's constitution. Despite a High Court order in June 2020, that declared some of the lockdown rules unconstitutional (see SAFLII 2020 for the court ruling; also, Rumney 2020), the South African government has reinforced the impression of its authoritarian approach by simply ignoring it and forging ahead with its implementation of stringent lockdown rules. And because most people do not know about this High Court order (and are also ignorant of the success of Sweden's refusal to lock down), they simply continue submitting obediently to the ANC government's authoritarian restrictions. 


\section{Olivier}

\section{"Vaccines"?}

As already argued above, we are witnessing what could be a deciding moment in the history of humankind, because of the ever-widening chasm between those people who follow what their arguably authoritarian governments dictate, on the one hand, and those who appeal to their constitutionally embedded right to choose what to do about the socalled "pandemic." In addition to the other areas, discussed earlier, where this differend manifests itself today, there is the issue of "vaccines"-and I put the word in scare quotes because part of the differend centring on it are the divergent opinions between representatives of the two distinct camps, whether it is indeed a vaccine or not. After all, a vaccine - such as that against smallpox, for example - provides immunity against a disease, and therefore prevents one from being infected, while the Covid-19 "vaccines" do nothing of the sort. On the "authoritative" World Health Organisation's website (WHO Covid-19 vaccines: n.d.) it tells us:

Safe and effective vaccines will be a gamechanger: but for the foreseeable future we must continue wearing masks, physically distancing and avoiding crowds. Being vaccinated does not mean that we can throw caution to the wind and put ourselves and others at risk, particularly because it is still not clear the degree to which the vaccines can protect not only against disease but also against infection and transmission.

There have been several reports that have provided more clarity in this regard, however, to the effect that vaccinated people do in fact get infected by the coronavirus again. So, for instance, in May it was reported (Morris 2021; see also Nsubuga 2021; and Horton 2021) that in the Seychelles, with the highest population vaccination percentage in the world at that time, there was a "surge" in coronavirus infections, and that of these about a third comprised people who had received two vaccinations. With such a high degree of vaccination it is more than likely that at least some of the transmissions or reinfections came from vaccinated people. Even the American Centers for Disease Control and Prevention (CDC 2021), while stating the official position regarding the efficacy of the "vaccines" at the outset, admits that:

Covid-19 vaccines are effective. However, a small percentage of people who are fully vaccinated will still get Covid-19 if they are exposed to the virus that causes it. These are called "vaccine breakthrough cases." This means that while people who have been vaccinated are much less likely to get sick, it will still happen in some cases. It's also possible that some fully vaccinated people might have infections, but not have symptoms (asymptomatic infections).

From the above it should be clear what the official narrative about "vaccines"- as part of the official response to the "pandemic" - amounts to, namely that being vaccinated will be a "gamechanger" in so far as these treatments can be - in fact, are - claimed to be effective against Covid-19, despite the fact that they do not (as vaccinations are supposed to do) immunise one against the disease, nor guarantee prevention of transmission or infection. Perhaps this is implicitly justified by the fact that the Covid- 


\section{Olivier}

19 "vaccines" have only been given authorisation for "emergency use" by the American FDA (see for example Pfizer n.d.).

This marks one side (the official narrative) of the differend in question. The side of the "resistance" can be introduced by citing the "Declaration of Canadian Physicians for Science and Truth" (2021), which might be cited by the "resistance" as a sign that some medical doctors in the world still have the integrity to stand up to what it claims to be politically motivated coercion (such as economically debilitating lockdowns), supposedly in the name of science. The declaration, by about 10000 Canadian doctors, states that on 30 April 2021, Ontario's physician licensing body, the College of Physicians and Surgeons of Ontario (CPSO), issued a statement forbidding physicians from questioning or debating any or all of the official measures imposed in response to Covid-19. "The CPSO then went on to threaten physicians with punishmentinvestigations and disciplinary action. We regard this recent statement of the CPSO to be unethical, anti-science and deeply disturbing," their declaration reads. The doctors object to what they say is tantamount to forcing them to put aside scientific methods and avoid debate around contentious issues such as lockdown measures as discussed in what is known as the Great Barrington Declaration (2020), which opens with the statement (constitutive of the differend in question):

The Great Barrington Declaration-As infectious disease epidemiologists and public health scientists we have grave concerns about the damaging physical and mental health impacts of the prevailing Covid-19 policies [those of the "official" narrative; B.O.], and recommend an approach we call Focused Protection.

The Canadian doctors (Declaration of Canadian Physicians for Science and Truth 2021) also accuse the CPSO of limiting free speech and not fully informing patients and the public of the "risks, benefits and any alternatives to the treatment or intervention" regarding the virus, before getting their consent. They go so far as to say that the vaccine roll-outs go against the historical Nuremberg Code which forbade any medical experiments similar to those conducted by the Nazis in concentration camps, and argue that lockdowns have imposed their own suffering on society, in the guise of an increase in depression and suicide, delayed investigation and treatment of cancer, ballooning surgical waiting lists and increased rates of child and domestic abuse. Importantlybecause it highlights one of the main manifestations of the differend under discussion, namely the question of the legitimate role of science in the context of the "pandemic"these doctors state (Declaration of Canadian Physicians for Science and Truth 2021):

We also give notice to other Canadian and international licensing authorities for physicians and allied professions that the stifling of scientific inquiry and any order to violate our conscience and professional pledge to our patients, itself may constitute a crime against humanity.

These doctors prioritise the question of scientific method in the present context, in light of the well-known practice of scientific debate. Instead of scientists agreeing about 


\section{Olivier}

everything every step of the way, there is constant dialogue and argumentation among them concerning hypotheses put forward about phenomena in the scientific field concerned. As the Canadian doctors point out, advances in science occur when official narratives are questioned and independent paths are pursued. Why is this relevant in relation to the (experimental) "vaccines"? Precisely because, under conditions relating to the "pandemic," people (including scientists) are asked to believe unquestionably what the officially sanctioned narrative dictates regarding lockdowns (as the doctors observe), for example. One might add that this is also true of Covid-19 vaccines-one of the most taboo subjects of discussion today; ironically, given that, in the scientific and ethical interest of public safety, it should be the most vigorously discussed. These were developed at breakneck speed (Solis-Moreira 2020), contrary to all previous scientific protocols, eschewing the normal, time-consuming and painstaking animal and human testing to ensure their safety. This makes them "experimental vaccines," one might argue, with all the vaccinated people in the world effectively taking part in ongoing clinical trials. The "resistance" can safely argue this, because on the WHO website (2020), of all places, the following information is encountered:

Most vaccines have been in use for decades, with millions of people receiving them safely every year. As with all medicines, every vaccine must go through extensive and rigorous testing to ensure it is safe before it can be introduced in a country's vaccine programme.

Each vaccine under development must first undergo screenings and evaluations to determine which antigen should be used to invoke an immune response. This preclinical phase is done without testing on humans. An experimental vaccine is first tested in animals to evaluate its safety and potential to prevent disease.

If the vaccine triggers an immune response, it is then tested in human clinical trials in three phases.

Given that, despite this solemn reassurance by WHO, the Covid-19 vaccines were not subjected to such supposedly time-consuming, rigorous testing, it is not at all surprising to find medical doctors taking issue with their distribution throughout the world. So, for example, warnings regarding the vaccines' lack of safety have been issued by a group of 160 medical doctors (World Doctors Alliance 2021), as well as one comprising 57 leading scientists and medical doctors (Breaking News-CA 2021). On the website of the World Doctors Alliance (2021) it is reported that:

Dozens of medical experts issued a warning this month about Covid-19 vaccines, slamming the jabs as "unnecessary, ineffective and unsafe" and likely to lead to "foreseeable mass deaths."

"In short, the available evidence and science indicate that Covid-19 vaccines are unnecessary, ineffective and unsafe," Doctors for Covid-19 Ethics said in an open letter two weeks ago. "Actors authorizing, coercing or administering experimental Covid-19 


\section{Olivier}

vaccination are exposing populations and patients to serious, unnecessary, and unjustified medical risks."

The article (Breaking News-CA 2021) by the 57 scientists referred to above is just as uncompromising in stressing these doctors' opposition to the current batch of (mainly the Pfizer, Moderna, AstraZeneca and Johnson \& Johnson) vaccines. Here is their paper abstract (note the scientific terminology, such as "autoimmunity" [literally the immunity against one's own immune system, which would therefore no longer function] and their call for dialogue):

Since the start of the Covid-19 outbreak, the race for testing new platforms designed to confer immunity against SARS-CoV-2, has been rampant and unprecedented, leading to emergency authorisation of various vaccines. Despite progress on early multidrug therapy for Covid-19 patients, the current mandate is to immunise the world population as quickly as possible. The lack of thorough testing in animals prior to clinical trials, and authorisation based on safety data generated during trials that lasted less than 3.5 months, raise questions regarding the safety of these vaccines.

Given the high rate of occurrence of adverse effects, and the wide range of types of adverse effects that have been reported to date, as well as the potential for vaccinedriven disease enhancement, Th2-immunopathology, autoimmunity, and immune evasion, there is a need for a better understanding of the benefits and risks of mass vaccination, particularly in the groups that were excluded in the clinical trials.

Despite calls for caution, the risks of SARS-CoV-2 vaccination have been minimised or ignored by health organisations and government authorities. We appeal to the need for a pluralistic dialogue in the context of health policies, emphasising critical questions that require urgent answers if we wish to avoid a global erosion of public confidence in science and public health.

It will be noticed that this information on the position of the "resistance" appears on "alternative" websites, and the reason is obvious - most mainstream websites censor or reject any viewpoints that challenge the official narrative without entering into debate or dialogue - which is, from the perspective of the dissenting doctors and scientiststotally unscientific. This is all the more true, because of the proliferation of cautionary assessments of the vaccines; here is another one on a report from a French drug assessment centre (Smits 2021):

A regional independent drug assessment center, the CTIAP (Centre territorial d'Information indépendante et d'Avis pharmaceutiques), which is linked to the Cholet public hospital in the west of France, recently published a report showing that the vaccines used against Covid were not only submitted to insufficient clinical testing, but that the quality of the active substances, their "excipients, some of which are new," and the manufacturing processes are problematic. "These new excipients should be considered as new active substances," the Cholet hospital team stated, in a study that according to them raises issues that have not been commented [sic] to date ... 


\section{Olivier}

The authors of the report consider that the "variabilities, which impact the very core of the product, could even invalidate any clinical trials conducted" in the coming months and years. They go so far as to state: "Prudence would even dictate that, in all countries where these vaccines against Covid-19 have been marketed, all the batches thus released should be withdrawn immediately; and that these MAs that have been granted should be suspended, or even canceled, as a matter of urgency until further notice."

Despite these concerns regarding the supposed safety of the Covid-19 vaccines, the mainstream or official narrative routinely reassures people of their safety (for example Rodriguez 2021). As the 57 scientists and doctors' statement (above) implies, it is only if all questions concerning Covid-19 were to be pursued in a dialogically open, scientifically responsible manner, that there would be any chance of reaching agreement or consensus on these vexing issues. Yet, in so far as the differences of opinion regarding these Covid-19 "vaccines" register an undeniable differend, I believe that the underlying "rules of judgement" of either side in this matter are incommensurable and irreconcilable, and that therefore no such consensus can be reached at present-it could only happen if either side (or both) fundamentally changes or abandons the "rules of judgement" it currently employs. After all, how do you reconcile two sides when one insists that the vaccines are safe (based on limited testing, putatively because of the "pandemic emergency" at hand), while the other points to ample evidence of adverse side-effects and death among recipients of the vaccines? It is not difficult to ascertain that there are many conflicting reports about their safety (see Mallapaty and Callaway 2021; RT News 2021 - just two among many such reports), which underscore my claim, that a differend is at work in this fraught terrain. In both of these reports one witnesses mutually incompatible claims, side by side, about the efficacy of the vaccines, on the one hand, and their adverse effects, on the other. For lack of space, I leave aside the related question of alternative treatments that have shown efficacy against the coronavirus, such as Ivermectin (see Olivier 2021a), among others.

\section{What would it Take to Remove this Differend?}

Recalling Lyotard's (1984, 60-61) allusion to a second type of "consensus," namely one that is coerced through manipulation of the "system," there are arguably clear indications that the official side in the present situation is trying to force a consensus (through a veritable army of so-called fact-checkers, such as those under the aegis of Reuters), but cannot actually succeed (even if, to its supporters, it ostensibly does succeed), because the other side, the "resistance," is just as actively challenging the claims promoted and policies pursued by the mainstream. To make matters worse, while one might argue that one side is evidently dogmatic in its claims while the other is not, both adduce (at least ostensible) evidence for their claims. So, what would succeed in removing the incommensurability of the respective sides' claims (and hence the differend) regarding the various aspects of the "pandemic," or-as it was formulated earlier - in changing or abandoning the "rules of judgement" it currently applies? 


\section{Olivier}

To begin with, it is doubtful whether anything either side-vehemently committed to its own version of the "proper" response to the "pandemic"-could produce would initiate a shift towards a point where one of them would abandon its position in favour of the other. This would arguably remove the present differend by dissolving the reasons for its emergence in the first place. What might pave the way for a "disappearance" (if not the dissolution) of the differend would be either the successful enforcement of (pseudo-)consensus by manipulation of the system (mainly via the media) by the official narrative, or the (unlikely) colossal growth of support for the resistance, initiated by something like the very "popular" (that is, massively viewed) video of Dr Sam White (referred to earlier in the context of PCR-tests). In this video he outlines his reasons for distancing himself from the NHS in Britain for its systematic deception of patients about various aspects of Covid-19, including the potentially lethal dangers of being "vaccinated" with something that is not a true vaccine, but a form of genetic treatment (O'Sullivan 2021). Something like this could potentially shift the balance in favour of the "resistance," although it is highly unlikely in view of the huge advantage enjoyed by the official discourse through its control of mainstream media, institutions such as the WHO, the WEF and governments worldwide.

It is more likely that, if the resistance stood any chance to turn the tables despite its comparative paucity of (mainstream) means of persuasion, an "event" that carries considerable institutional weight would have to occur-not that the millions of electronically mediated messages on platforms like WhatsApp, and especially Signal and Telegram (which are not as compromised as WhatsApp, owned as it is by mainstream colossus, Facebook) don't play an important role in winning supporters for the resistance. But I am rather thinking of something like the following regarding what is being loosely called the "Nuremberg 2 trials" in some "resistance" circles, where lawyers, under the leadership of Dr Reiner Fuellmich (referred to earlier in relation to PCR-tests) are preparing a class action case against the World Health Organisation (WHO) and other parties (Breaking-News. CA 2021[2]):

A team of over 1000 lawyers and over 10000 medical experts led by Dr Reiner Fuellmich have begun legal proceedings against the CDC, WHO and the Davos Group for crimes against humanity. Fuellmich and his team present the faulty PCR test and the order for doctors to label any comorbidity death as a Covid death as fraud. The PCR test was never designed to detect pathogens and is $100 \%$ faulty at 35 cycles. All the PCR tests overseen by the CDC are set at 37 to 45 cycles. The CDC admits that any tests over 28 cycles are not admissible for a positive reliable result. This alone invalidates over $90 \%$ of the alleged Covid cases / "infections" tracked by the use of this faulty test.

In addition to the flawed tests and fraudulent death certificates, the "experimental" vaccine itself is in violation of Article 32 of the Geneva Convention. Under Article 32 of the 1949 Geneva Convention IV, "mutilation and medical or scientific experiments not necessitated by the medical treatment of a protected person" are prohibited. According to Article 147, conducting biological experiments on protected persons is a grave breach of the Convention. 


\section{Olivier}

The "experimental" vaccine is in violation of all 10 of the Nuremberg Codes which carry the death penalty for those who seek to violate these International Laws.

Just how serious the charges against these organisations are, becomes apparent when one reads further that the Covid-19 "vaccines" are described in these uncompromising terms (Breaking-News. CA 2021[2]):

The "vaccine" fails to meet the following five requirements to be considered a vaccine and is by definition a medical "experiment" and trial:

\section{Provides immunity to the virus}

This is a "leaky" gene therapy that does not provide immunity to Covid and claims to reduce symptoms yet double-vaccinated are now $60 \%$ of the patients requiring ER or ICU with covid infections.

\section{Protects recipients from getting the virus}

This gene-therapy does not provide immunity and double-vaccinated can still catch and spread the virus.

\section{Reduces deaths from the virus infection}

This gene-therapy does not reduce deaths from the infection. Double-Vaccinated infected with Covid have also died.

\section{Reduces circulation of the virus}

This gene-therapy still permits the spread of the virus as it offers zero immunity to the virus.

\section{Reduces transmission of the virus}

This gene-therapy still permits the transmission of the virus as it offers zero immunity to the virus.

Add to this what the stipulations of the Nuremberg Code, adopted after WW II to prevent a recurrence of the scientific and medical experiments performed by the Nazis, unambiguously forbid, then it should be crystal clear that-if it can be convincingly demonstrated, and ruled, in a court of law, that the development and administering of the Covid-19 "vaccines" violate this Code, and if the representatives of the official discourse recognised this ruling and would abide by it (all big "ifs") - the differend in question might "disappear," even if it would not be dissolved. The articles of the Nuremberg Code, all of which have, according to Dr Fuellmich and his team, been violated by the development and administering of the experimental "vaccines," state (I shall only list them without their respective elaborations; Breaking-News.CA 2021[2]):

Nuremberg Code \#1: Voluntary Consent is Essential

Nuremberg Code \#2: Yield Fruitful Results Unprocurable by Other Means 


\section{Olivier}

Nuremberg Code \#3: Base Experiments on Results of Animal Experimentation and Natural History of Disease

Nuremberg Code \#4: Avoid All Unnecessary Suffering and Injury

Nuremberg Code \#5: No Experiment to be Conducted if There's Reason to Think Injury or Death Will Occur

Nuremberg Code \#6: Risk Should Never Exceed the Benefit

Nuremberg Code \#7: Preparation Must Be Made Against Even Remote Possibility of Injury, Disability or Death

Nuremberg Code \#8: Experiment Must Be Conducted by Scientifically Qualified Persons

Nuremberg Code \#9: Anyone Must Have the Freedom to Bring the Experiment to an End at Any Time

Nuremberg Code \#10: The Scientist Must Bring the Experiment to an End at Any Time if There's Probable Cause of it Resulting in Injury or Death

As a final indictment, Fuellmich and his team declare (Breaking-News. CA 2021[2]):

It is clear in the statistical reporting data that this experiment is resulting in death and injury yet all the politicians, drug companies and so-called experts are not making any attempt to stop this gene-therapy experiment from inflicting harm on a misinformed public.

\section{Conclusion}

In light of the preceding argument, together with all the evidence adduced to demonstrate that a global differend has been in force for some time now-since the contours of two opposing sides started taking shape not too long after the beginning of the so-called "pandemic" (I would say around the time that other countries started following China's example of declaring a "lockdown") — it seems to me safe to say that the everyday manifestations of this differend have had, and continue to have, farreaching consequences for ordinary people's everyday lives. Unlike the lives of the global elites (Carter 2020; Castells 2010, 445-448), their lives have been turned upside down by everything listed and discussed in this paper, from lockdowns through PCRtests to the pressure to be vaccinated. This does not seem, at the time of writing this paper (July 2021), to be something that is likely to change for the better soon-unless an institutional event such as the one alluded to in the discussion, above, of the international court case being pursued by Dr Reiner Fuellmich and his (international) team, were to yield unexpected results. This is not impossible, given the explosive nature of the interview Dr Fuellmich conducted with Dr David Martin in July 2021 (The 


\section{Olivier}

Truth Hunter 2021), referred to earlier in this paper. In the meantime, only hope prevails for the "resistance," of which I am a member, regardless of the fact that I am able to assess the global "pandemic" situation reasonably dispassionately, as I have attempted to do here. As a philosopher - and as Socrates taught us - I have no choice but to refuse paying obeisance to the "gods of the city"-those that bestow power on the ruling "elites" (Castells 2010, 445-448; Olivier 2013) - including the WEF, the WHO, the mainstream media, the corporations and the banks. And from the perspective of the resistance, "justice" for those who are the current "victims" (in the Lyotardian sense) could only prevail if (as my reviewer-critic reminded me) one "phrase regimen" (rule of judgement) - that of the WEF, the CDC, the WHO, etc. - were to be eradicated in a manner such as that described above as an institutionally contextualised "event." This is corroborated by Gratton $(2018,3.3)$, who argues that, for Lyotard, "... the politics of the differend does not call for valuing different discourses equally or one recognizing another, since, of course, conflict occurs precisely where neither side finds meaning in the phrase regimen of the other. Lyotard thus does not model the different phrase regimens as a marketplace of ideas, since the existence of one phrase regimen may mean the violent silencing of another." Further, Gratton $(2018,3.3)$ says: "This is what gives us the ability to name the unjust." Given the growing resistance against the mainstream narrative, one can only trust that justice will prevail in the end, and a more humane future awaits us, compared to the fraught present.

\section{Acknowledgement}

The author wishes to thank the National Research Foundation of South Africa, which contributed financially to making the research possible that led to the publication of this article.

\section{References}

Astuti, I., and Ysrafil. 2020. "Severe Acute Respiratory Syndrome Coronavirus 2 (SARS-CoV2): An overview of viral structure and host response." 18 April. Accessed June 21, 2021. https://www.ncbi.nlm.nih.gov/pmc/articles/PMC7165108/\#: :text=Structurally\%2C\%20S ARS\%2DCoV\%2D2,several\%20accessory\%20proteins\%20\%5B9\%5D.

BBC News. 2021. "Why are People Talking about Dr Anthony Fauci’s Emails?” BBC News, 2 June. Accessed June 24, 2021. https://www.bbc.com/news/world-us-canada-57336280.

Berenbaum, M. 2021. “Adolf Eichmann-German Military Official.” Brittanica, 27 May. Accessed July 6, 2021. https://www.britannica.com/biography/Adolf-Eichmann.

Breaking News-CA. 2021. "57 Top Scientists and Doctors Release Shocking Study on Covid Vaccines and Demand immediate stop to ALL Vaccinations." 10 May. Accessed July 9, 2021. https://breaking-news.ca/57-top-scientists-and-doctors-release-shocking-study-oncovid-vaccines-and-demand-immediate-stop-to-all-vaccinations/. 


\section{Olivier}

Breaking News-CA. 2021[2]. "1,000 Lawyers and 10,000 Doctors have Filed a Lawsuit for Violations of the Nuremberg Code." 3 May. Accessed July 10, 2021. https://breakingnews.ca/the-new-nuremberg-trials-2021-please-share-this-info/.

Carrington, D. 2020. 'Coronavirus: 'Nature is Sending us a Message', says UN Environment Chief." The Guardian (Environment), 25 March. Accessed April 10, 2020. https://www.theguardian.com/world/2020/mar/25/coronavirus-nature-is-sending-us-amessage-says-un-environment-chief.

Carter, Z. D. 2020. "The Rich Are Having Themselves a Fine Coronavirus." Huffpost (Politics), 17 April. Accessed July 7, 2020. https://www.huffpost.com/entry/richcoronavirus-bailout-stimulus-banks_n_5e9762acc5b686ec1570cb44.

Castells, M. 2010. The Rise of the Network Society. Second edition. Oxford: Wiley-Blackwell.

CDC. 2021. "What you Should Know about the Possibility of Covid-19 Illness after Vaccination." CDC Covid-19, 25 June. Accessed July 7, 2021. https://www.cdc.gov/coronavirus/2019-ncov/vaccines/effectiveness/why-measureeffectiveness/breakthrough-cases.html.

CDC 2021a. 07/21/2021: "Lab Alert: Changes to CDC RT-PCR for SARS-Cov-2 Testing: CDC, 21 July." Accessed August 8, 2021. https://www.cdc.gov/csels/dls/locs/2021/07-212021-lab-alert-Changes_CDC_RT-PCR_SARS-CoV-2_Testing_1.html.

Chossudovsky, M. 2021. The 2020-21 Worldwide Corona Crisis: Destroying Civil Society, Engineered Economic Depression, Global Coup d'État and the “Great Reset.” Global Research E-Book, Centre for Research on Globalization (CRG). Accessed June 24, 2021. https://www.globalresearch.ca/the-2020-worldwide-corona-crisis-destroying-civil-societyengineered-economic-depression-global-coup-detat-and-the-great-reset/5730652.

Declaration of Canadian Physicians for Science and Truth. 2021. Accessed June 2021. https://canadianphysicians.org/.

Fuellmich, R. 2021. Watch / Dr Reiner Fuellmich / Nuremberg 2 / "Those Involved in the Coronavirus Scare should be Tried for Crimes against Humanity.” Breaking-News.Ca: 24 May. Accessed July 17 2021. https://breaking-news.ca/watch-dr-reiner-fuellmichnuremberg-2-those-involved-in-the-coronavirus-scare-should-be-tried-for-crimes-againsthumanity/.

Fuellmich, R. 2021a. Jorn Luka-The Trueman Show \#29 Dr Reiner Fuellmich, 10 June 2021. Accessed June 30, 2021. https://www.youtube.com/watch?v=sJXCG3tXwj4.

Fuellmich. n.d. "Dr Reiner Fuellmich's Law Firm.” Accessed May 7, 2021. https://www.fuellmich.com/ and for video addresses: https://www.fuellmich.com/news/.

GAVI. 2020. “Do Lockdowns Actually Work?” GAVI, 12 June. Accessed July 4, 2021. https://www.gavi.org/vaccineswork/do-lockdowns-actually-work. 


\section{Olivier}

Gratton, P. 2018. "Jean François Lyotard." The Stanford Encyclopedia of Philosophy (Winter 2018 Edition), edited by Edward N. Zalta. Accessed Aug 19, 2021. https://plato.stanford.edu/archives/win2018/entries/lyotard/\#Diff.

Guterl, F. 2021. "The Wuhan Lab and the Virus: The Dr Fauci, Rand Paul Debate Factchecked and Explained.” Newsweek, 14 May. Accessed June 24, 2021. https://www.newsweek.com/wuhan-lab-virus-dr-fauci-rand-paul-debate-fact-checkedexplained-1591414.

Habermas, J. 1990. Moral Consciousness and Communicative Action. Translated by Lenhardt, C. and Nicholsen, S.W. Cambridge, Mass.: The MIT Press.

Health Feedback. 2020. "The Group World Doctors Alliance Spreads Misinformation about the Impact of the Covid-19 Pandemic, the Virus, and the Reliability of Diagnostic Tests." 22 October. Accessed July 9, 2021. https://healthfeedback.org/claimreview/the-groupdoctors-for-truth-spreads-misinformation-about-the-impact-of-the-covid-19-pandemic-thevirus-and-the-reliability-of-diagnostic-tests/.

Horton, T. 2021. "Andrew Marr Urges Caution after Catching Covid despite being Fully Vaccinated.” Yahoo News, 28 June. Accessed July 7, 2021. https://uk.yahoo.com/news/andrew-marr-urges-caution-catching-152106969.html.

Jawerth, N. 2020. "How is the Covid-19 Virus Detected using Real Time RT-PCR?" IAEA 27 March. Accessed January 7, 2021. https://www.iaea.org/newscenter/news/how-is-thecovid-19-virus-detected-using-real-time-rt-pcr.

Johnson, C. K. 2021. "Why we don't Know the Animal Origins of the Coronavirus." Scientific America, 9 June. Accessed June 23, 2021.

https://www.scientificamerican.com/article/finding-conclusive-animal-origins-of-thecoronavirus-will-take-time/\#.

Kupferschmidt, K. 2020. "How the Pandemic Made this Virologist an unlikely Cult Figure." Science, 28 April. Accessed June 27, 2021.

https://www.sciencemag.org/news/2020/04/how-pandemic-made-virologist-unlikely-cultfigure.

Lister, T., and S. Shukla. 2020. "Sweden Challenges Trump — and Scientific Mainstream-by Refusing to Lock Down.” CNN, 10 April. Accessed July 4, 2021.

https://edition.cnn.com/2020/04/10/europe/sweden-lockdown-turmp-intl/index.html.

Lyotard, J-F. 1984. The Postmodern Condition: A Report on Knowledge. Translated by G. Bennington and B. Massumi. Minneapolis: University of Minnesota Press. https://doi.org/10.2307/1772278.

Lyotard, J-F. 1988. The Differend: Phrases in Dispute. Translated by G. van den Abbeele. Manchester: Manchester University Press. 


\section{Olivier}

Mallapaty, S., and E. Callaway. 2021. "What Scientists Do and Don't Know about the OxfordAstraZeneca Covid Vaccine.” Nature-News explainer, 25 March. Accessed July 9, 2021. https://www.nature.com/articles/d41586-021-00785-7.

Maxman, A., and S. Mallapaty. 2021. "The Covid Lab-leak Hypothesis: What Scientists Do and Don't Know." Nature, 8 June. Accessed June 24, 2021. https://www.nature.com/articles/d41586-021-01529-3.

McGee, L. 2021. "Five Years after the Brexit Vote, the United Kingdom Is more divided than ever." CNN World, 23 June. Accessed July 3, 2021.

https://edition.cnn.com/2021/06/23/uk/brexit-five-years-on-analysis-intl-cmd/index.html.

McIntosh, I. 1997. "Australian Aboriginal Property Rights under Threat.” Cultural Survival Quarterly Magazine, June. Accessed July 7, 2021.

https://www.culturalsurvival.org/publications/cultural-survival-quarterly/australianaboriginal-property-rights-under-threat.

McLennan, M. 2018. “Differend and 'Post-truth'.” French Journal for Media Research. Accessed August 19, 2021. http://frenchjournalformediaresearch.com/lodel1.0/main/index.php?id=1437\#ftn1.

McLeod, S. 2017. “The Milgram Shock Experiment.” Simply Psychology, 2017. Accessed July 5, 2021. https://www.simplypsychology.org/milgram.html.

McLeod, S. 2020. “The Stanford Prison Experiment.” Simply Psychology, 2020. Accessed July 6, 2021. https://www.simplypsychology.org/zimbardo.html.

Merriam-Webster Online Dictionary. n.d. “'Pandemic' vs 'Epidemic'-How they overlap and where they differ." Accessed June 29, 2021. https://www.merriam-webster.com/words-atplay/epidemic-vs-pandemic-difference.

Morris, J. 2021. "Island Paradise with Highest Vaccination Rate Reports World's biggest Covid Surge.” Yahoo News, 5 May. Accessed July 7, 2021.

https://uk.news.yahoo.com/seychelles-highest-vaccination-covid-surge-170412980.html.

Nsubuga, J. 2021. "Here are the Top Five Covid Symptoms if you've been Vaccinated, according to Experts." Yahoo News, 24 June. Accessed June 25, 2021.

https://uk.yahoo.com/news/top-five-covid-symptoms-vaccinated-zoe-app-171317837.html.

Olivier, B. 2013. "Time(s), Space(s) and Communication in Castells's Network Society." Communicare (Journal for Communication Sciences in South Africa) 32 (2): 20-39.

Olivier, B. 2020. "Freud on Group Psychology and Leaders: The Case of Donald Trump." Psychotherapy and Politics International, 2020, Early View: 1-13. https://doi.org/10.1002/ppi.1569. 


\section{Olivier}

Olivier, B. 2020a. "Die Covid-19 Pandemie: 'n Geleentheid tot Besinning oor die Mens se Plek in Verhouding met die Natuur?" Tydskrif vir Geesteswetenskappe (Journal for the Humanities) 60 (4-2): 1103-1131. https://org.doi.10.17159/2224-7912/2020/v60n4-2a1.

Olivier, B. 2021. "The Libeskind Jewish Museum in Berlin, the Unpresentable and Experience.” Acta Academica 53 (1): 23-43. https://doi.org/10.18820/24150479/aa53i1.2.

Olivier, B. 2021a. "The Case for Ivermectin." Posted on the Mail \& Guardian's Thought Leader site, 18 January. Accessed February 4, 2021. https://thoughtleader.co.za/bertolivier/2021/01/18/the-case-for-ivermectin/.

O’Sullivan, J. 2021. “Doctor's Damning Legal Letter on NHS Covid Misconduct.” Principia Scientific International, 3 July. Accessed July 9, 2021. https://principiascientific.com/doctors-damning-legal-letter-on-nhs-covidmisconduct/?utm_source=feedburner\&utm_medium=email\&utm_campaign=Feed $\% 3 \mathrm{~A}+\mathrm{ps}$ intl+\%28Principia+Scientific+Intl+-+Latest+News\%29.

Pfizer. n.d. "Our Science: Coronavirus Disease (Covid-19) Resources.” Accessed July 7, 2021. https://www.pfizer.com/science/coronavirus.

Pittaway, D. 2020. “Coronavirus, Meaningless Numbers, Disaster Capitalism: Oligarchy's Dream Come True." Mail and Guardian's Thought Leader site, 11 May. Accessed January 7, 2021. https://thoughtleader.co.za/coronovirus-meaningless-numbers-disaster-capitalismoligarchys-dream-come-true/.

Racaniello, V. 2020. “There is One, and only One Strain of Sars-CoV-2." Virology Blog, 7 May. Accessed June 27, 2021. https://www.virology.ws/2020/05/07/there-is-one-and-onlyone-strain-of-sars-cov-2/.

Reuters Staff. 2020. "Fact Check: Inventor of Method Used to Test for Covid-19 Didn't Say it can't be Used in Virus Detection.” Reuters, 13 November. Accessed June 26, 2021. https://www.reuters.com/article/uk-factcheck-pcr-idUSKBN24420X.

Reuters Staff 2. 2020. "Fact Check: Studies Show Covid-19 Lockdowns Have Saved Lives." Reuters Everything News, 24 November. Accessed June 26, 2021. https://www.reuters.com/article/uk-factcheck-lockdowns-idUSKBN2842WS..

Rodriguez, C. H. 2021. "How can Covid Vaccines be Safe when they Were Developed so Fast?" GAVI, 31 March. Accessed July 9, 2021. https://www.gavi.org/vaccineswork/askkhn-politifact-how-can-covid-vaccines-be-safe-when-they-were-developed-sofast?gclid=EAIaIQobChMI-Licrf_V8QIVUu3tCh1TOALOEAAYAiAAEgLLBPD_BwE.

RT News. 2021. "Over 3,800 Germans got Sick with Covid-19 Following Full Vaccination, Hundreds were Hospitalized—Health Watchdog.” 8 July. Accessed July 9, 2021. https://www.rt.com/news/528729-germans-sick-covid-full-vaccination/. 


\section{Olivier}

Rumney, E. 2020. “Court Rules some South African Lockdown Restrictions Invalid.” Reuters, 2 June. Accessed July 6, 2021. https://www.reuters.com/article/us-health-coronavirussafrica-court-idUSKBN2392BV.

SAFLII. 2020. "De Beer and Others v Minister of Cooperative Governance and Traditional Affairs" (21542/2020) [2020] ZAGPPHC 184; 2020 (11) BCLR 1349 (GP) (2 June 2020). Accessed July 7, 2021. http://www.saflii.org/za/cases/ZAGPPHC/2020/184.html.

Shahar, E. 2021. "Not a Shred of Doubt: Sweden was Right.” Eyal Shahar, 27 May. Accessed June 8, 2021. https://shahar-26393.medium.com/not-a-shred-of-doubt-sweden-was-right32e6dab1f47a.

Smits, J. 2021. "French Drug Assessment Center Demands Removal of all Four Widely Used Covid Vaccines.” LifeSite News, 22 April. Accessed July 10, 2021.

https://www.lifesitenews.com/news/french-drug-assessment-center-demands-removal-ofall-four-widely-used-covid-vaccines.

Solis-Moreira, J. 2020. "How Did we Develop a Covid-19 Vaccine so quickly?" Medical News Today, 15 December. Accessed July 8, 2021.

https://www.medicalnewstoday.com/articles/how-did-we-develop-a-covid-19-vaccine-soquickly.

Sones/America's Frontline Doctors. 2021. Global Research, 23 June. Accessed June 28, 2021. Lisbon Court Rules Only $0.9 \%$ of "Verified Cases" Died of Covid, numbering 152, not 17,000 claimed. https://www.globalresearch.ca/lisbon-court-rules-only-0-9-verified-casesdied-covid-numbering-152-not-17000-claimed/5748807.

The Great Barrington Declaration. 2020. Accessed and signed May 9, 2021. https://gbdeclaration.org/.

The Portugal News. 2020. “Covid PCR Test Reliability Doubtful-Portugal Judges.” News, 27 November. Accessed April 10, 2021. https://www.theportugalnews.com/news/2020-1127/covid-pcr-test-reliability-doubtful-portugal-judges/56962.

The Truth Hunter. 2021. "Reiner Fuellmich Interviews Dr David Martin who has some Mind Blowing Facts.” 12 July. Accessed July 12, 2021. https://brandnewtube.com/watch/reinerfuellmich-interviews-dr-david-martin-who-has-some-mind-blowingfacts_VXmTCZYmF8rHg3M.html.

Universal Declaration of Human Rights of the United Nations. 1948. Accessed July 7, 2021. https://www.un.org/en/about-us/universal-declaration-of-human-rights.

Walsh, N. P., and V. Cotovio. 2020. "Bats Are not to Blame for Coronavirus. Humans Are." CNN Health, 20 March. Accessed April 10, 2020.

https:/edition.cnn.com/2020/03/19/health/coronavirus-human-actions-intl/index.html. 


\section{Olivier}

WHO. 2020. “How Are Vaccines Developed?” WHO Newsroom, 8 December. Accessed July 8, 2021. https://www.who.int/news-room/feature-stories/detail/how-are-vaccinesdeveloped?gclid=EAIaIQobChMIjPKHtarT8QIVjtPtCh0bvgCkEAAYASAAEgIo7vD_B wE.

WHO PCR Tests. n.d. WHO website: Episode \#14 - Covid-19 - Tests. Accessed June 14, 2021. https://www.who.int/emergencies/diseases/novel-coronavirus-2019/mediaresources/science-in-5/episode-14---covid-19---tests?gclid=EAIaIQobChMInsO1n_08QIVqejtCh07fAEwEAAYASAAEgKmJvD_BwE.

WHO Covid-19 vaccines. N.d. WHO website. Accessed July 7, 2021. https://www.who.int/emergencies/diseases/novel-coronavirus-2019/covid-19-vaccines.

Woodward, A. 2020. “The Chinese CDC Now Says the Coronavirus Didn't Jump to People at the Wuhan Wet Market - instead, it Was the Site of a Super-spreader Event." Yahoo News, 29 May. Accessed June 10, 2020. https://uk.news.yahoo.com/chinese-cdc-nowsays-coronavirus-224900090.html.

World Doctors Alliance. 2021. "160+ Experts Slam Covid Vaccines as 'Unnecessary, Ineffective and Unsafe'.” 21 May. Accessed July 9, 2021. https://worlddoctorsalliance.com/blog/160-experts-slam-covid-vaccines/.

Worldometer Coronavirus. Accessed many times since April 2020. https://www.worldometers.info/coronavirus/\#countries. 